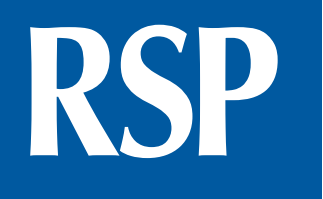

http://www.rsp.fsp.usp.br/
Revista de Saúde Pública

\title{
Implication of violence against women on not performing the cytopathologic test
}

\author{
Franciele Marabotti Costa Leite', Maria Helena Costa Amorim', Denise Petrucci Gigante \\ I Universidade Federal do Espírito Santo. Departamento de Enfermagem. Vitória, ES, Brasil \\ " Universidade Federal de Pelotas. Departamento de Nutrição. Programa de Pós-Graduação em Epidemiologia. \\ Pelotas, RS, Brasil
}

\section{ABSTRACT}

OBJECTIVE: To analyze the association between intimate partner violence and not performing the cytopathologic test in the last three years.

METHODS: It is a transversal study, performed in 26 health units in the city of Vitória, state Espírito Santo, from march to September 2014. The sample was constituted by 106 primary care female users, aging from 30 to 59 years-old. Data on cervical cancer screening were collected, besides the women's sociodemographic, behavior, obstetric, and gynecological characteristics by an interview, and the World Health Organization recommended tool for identifying violence experiences was applied. The analysis was performed through the chi-square test for association, linear trend for ordinal variables, and the Poisson regression analysis with robust variance.

RESULTS: Among the participating women, 14\% (95\%CI 12.0-17.2) had overdue Pap tests. Most women who did not perform the test had lower schooling levels, lower income, were smokers, in an unmarried union, having had their sexual debut before 15 years-old, three or more pregnancies, and two or more partners in the last 12 months. Women who suffered intimate partner sexual and physical violence were, respectively, $1.64(95 \% \mathrm{CI}-1.03-2.62)$ and 1.94 (95\% CI 1.28-2.93) times more delayed in the Pap tests than non-victims.

CONCLUSIONS: Violence is a significant exacerbating factor and affects women's health negatively. Women who are physically or sexually victimized by their partners are more vulnerable to not performing Pap tests and, consequently, have fewer chances of early diagnosing cervical cancer.

Franciele Marabotti Costa Leite

Departamento de Enfermagem - UFES Av. Marechal Campos, 1468 Maruípe 29040-090 Vitória, ES, Brasil

E-mail: francielemarabotti@gmail.com

Received: Sept 26, 2017

Approved: Jan 8, 2018

How to cite: Leite FMC, Amorim MHC, Gigante DP. Implication of violence against women on not performing the cytopathologic test. Rev Saude Publica. 2018;52:89.

Copyright: This is an open-access article distributed under the terms of the Creative Commons Attribution License, which permits unrestricted use, distribution, and reproduction in any medium, provided that the original author and source are credited.
DESCRIPTORS: Battered Women. Violence Against Women. Domestic Violence. Intimate Partner Violence. Uterine Cervical Neoplasms, prevention \& control. Papanicolaou Test. Health Care Quality, Access, and Evaluation. 


\section{INTRODUCTION}

Cervical cancer is the fourth most common neoplasia among women in the world. About 528,000 new cases of it occurred in 2012, which were responsible for 266,000 female deaths, representing $7.5 \%$ of all female cancer deaths. Around nine in each $10(87 \%)$ deaths due to this neoplasia happens in less developed regions. Mortality rates range from less than two per 100,000 in Western Asia, Western Europe and Australia, and to more than 20 per 100,000 in Melanesia (20.6) and Eastern Africa (27.6) ${ }^{1}$.

In Brazil, 16,340 new cases of cervical cancer were estimated for 2016-2017, a gross incidence of around 16 cases for each 100,000 women. It is the third most prevalent cancer, occupying the first position among women in the Northern region of the Country. It ranks in the second position in the Midwest and Northeast regions, while breast cancer is the most prevalent one, and the third and fourth positions for the Southeast and Southern regions, respectively ${ }^{2}$.

Since it is a public health issue, cervical cancer prevention strategies are essential. Vaccination against human papillomavirus (HPV), a risk factor for the disease development ${ }^{3}$, is a way of primary prevention, and the early diagnosis of injuries before they become invasive is highlighted as secondary prevention ${ }^{4}$.

The Instituto Nacional de Câncer (INCA - Brazilian National Cancer Institute) recommends, as a strategy for early detection, performing the cervical cytologic test, also known as Pap test, at every three years when there are two negative tests in an yearly gap. A sexually active woman should undergo the first test after 25 years-old and keep on performing it until she is 64. It may be interrupted when, after that age, the woman has at least two consecutive negative tests in the last five years ${ }^{5}$.

Not performing the Pap test is associated to the woman's characteristics, such as: age, marital status, schooling levels, and income ${ }^{6,7}$. Cultural issues, such as: fearing pain, shame, not knowing the procedure, place where the test takes place, and being discouraged by the partner are also reasons for resisting.

An epidemiologic case-control study showed that women with sexual violence history during childhood have less chances of performing the Pap test ${ }^{9}$. However, a population inquiry performed in the United States with women older than 18 points out that women who suffered intimate partner violence are more prone to cervical cancer screenings ${ }^{10}$.

The violence against women is an exacerbating factor in public health that affects a third of the world's female population, and the intimate partner is the main perpetrator ${ }^{11}$. Researches show the impact of violence in the victims' health, such as: cardiovascular and gastrointestinal disorders, and increase of pain and weariness complaints ${ }^{12,13}$. Besides, this phenomenon may be connected to not performing Pap tests ${ }^{9,10}$, one of the main strategies for cervical cancer early detection, which contributes to the reduction of incidence and mortality, as well as to physical, social, and psychological sequelae to the woman ${ }^{14}$.

This study had as it objective to analyze the association between intimate partner violence and not performing the cytopathologic test in the last three years.

\section{METHODS}

This is a transversal study, performed in 26 Health Units (US) in Vitória, state Espírito Santo, which were covered by the Estratégia de Saúde da Família (ESF - Family Health Strategy) or by the Programa de Agentes Comunitários (PACS - Community Agents Program). The data collected from March to September 2014 referred to service users who had intimate partners during the 12 previous months to the interview. An intimate partner was defined as a partner or ex-partner, regardless of formal union, and current boyfriends, given that they were having sexual relations. For the outcome definition, we adopted the Brazilian 
Ministry of Health guidelines for performing the cervical cancer screening: two negative consecutive annual tests, with a repetition after three years ${ }^{5}$. The dependent variable "overdue cytopathologic test" was defined as not having performed the test in the last three years previously to the interview. Considering the recommended age for beginning the test of 25 years-old and the interval of three years after two negative results, 706 women aging 30 years-old or older, who could have the overdue Pap test, were elected for this study.

To identify the interest exposition, the experience of intimate partner violence (IPV) in the 12 months previously to the interview, the tool called "World Health Organization Violence Against Women" (WHO VAW Study) was used. This tool aims to discriminate the different forms of violence against women in their psychological, physical and sexual domains. It comprises 13 questions related to violence, capable of discriminating its different manners in diverse social contexts, being over-reaching and relatively short. It was validated for Portuguese and considered as having high internal consistency. Psychological, sexual and physical violence were considered present when the interviewed women answered yes to one of the tool's items, and general violence was considered if she had experienced at least one of the three violence types ${ }^{15}$.

All the violence types were considered as exposition and its associations with the outcome. To estimate the sample size for a transversal study, we adopted a $95 \%$ trust level, with acceptable error of 5 percentage points, power of $80 \%$, prevalence of exposed women (non-victims) who performed the Pap test of 0.75 , and prevalence of non-exposed women (victims), who performed the Pap test, of 0.65 , admitting a non-performance prevalence around $20 \%$ and a relative risk of approximately 1.2. The total population of 83,160 adult women who should use the municipality's health units that had ESF or PACS was considered, with the population ranging from 858 to 12,189 according to the Health Unit. The sampling process was performed being proportional to the number of women registered in the Health Units, with a total necessary sample of 690 women.

Besides, to control the possible confounding variables, the sociodemographic characteristics were collected (age, race/color, schooling levels, marital status and family income), as well as behavior (alcoholic beverages ingestion, smoking, drug use history), and obstetric and gynecological ones (menarche age, current use of contraceptive methods, number of pregnancies, sexual debut age, and number of sex partners in the last 12 months).

The Pearson chi-square and linear trend tests were used in the bivariate analyses to investigate the possible association of confounding factors with the exposition and outcome, being the last one used only with ordinal variables. The robust Poisson regression was used in the analyses, registering the variables in the model if $p<0,20$ for the bivariate analysis, by the regressive selection, and keeping them in the model if $\mathrm{p}<0.05$.

Two predictive models were used in the adjusted analyses: model 1 (adjustment for sociodemographic variables); and model 2 (adjustment for sociodemographic, behavior, obstetric and gynecologic variables). We used prevalence ratio and its respective trust intervals as an effect measure. The analyses were performed in State 13.0.

The study was approved by the Research Ethics Committee of the Universidade Federal do Espírito Santo (Statement 470.744). The research was explained to the eligible women and they signed the informed consent form. An individual interview was performed privately in the Health Unit by duly trained interviewers. At the end of each interview, the Instituto Nacional de Câncer (National Cancer Institute) folder, containing all cervical cancer prevention and screening promotion guidelines, was given to the interviewee, as well as a folder designed by the research authors containing the main care services for women victims of violence.

\section{RESULTS}

The 706 women aging from 30 to 59 years-old who used the municipality's Health Units that had ESF or PACS participated in the study. Most of them were 30 to 39 years-old (43.3\%), 
declared themselves as brown (52.4\%), and had studied for more than eight years (63.7\%). Half of them were married and a third had a monthly family income above R $\$ 2,924,00$. About $34 \%$ drank alcoholic drinks, $12 \%$ were smokers, and $9 \%$ had drug use history. Around $82 \%$ of them had their menarche until 14 years-old and $22 \%$ did not currently use contraceptive methods. Almost half interviewees had had three or more pregnancies. The first sexual relation of 54\% of the women happened between the ages of 15 and 18 years-old, and more than $90 \%$ had at least one sexual partner in the last 12 months.

Among the interviewees, $14.5 \%$ (95\% CI 12.0-17.2) did not undergo a Pap test in the last three years. The highest prevalence of not performing the cytopathologic test was seen on the women who had studied up to eight years, who declared being in a consensual union, belonged to the lower income group, had drug use history, and smoked. Higher prevalence of not performing the test was also observed in women who had three or more pregnancies, had their sexual debut before 15 years-old and had two or more partners in the 12 months prior to the interview $(\mathrm{p}<0.05)$ (Table 1$)$.

Table 1. Sample characteristics and prevalence of overdue Pap test according to sociodemographic, behavior, obstetric, and gynecologic characteristics. Vitória, state Espírito Santo, March to September 2014. (n=706)

\begin{tabular}{|c|c|c|c|c|c|}
\hline \multirow{2}{*}{ Variable } & \multirow{2}{*}{$\mathbf{n}$} & \multirow{2}{*}{$\%$} & \multicolumn{3}{|c|}{ In the last three years } \\
\hline & & & $\%$ & $95 \% \mathrm{Cl}$ & $p$ \\
\hline \multicolumn{6}{|c|}{ Sociodemographic } \\
\hline Age (years) & & & & & 0.456 \\
\hline $30-39$ & 306 & 43.3 & 16.3 & $12.6-20.9$ & \\
\hline $40-49$ & 225 & 31.9 & 12.9 & $9.1-18.0$ & \\
\hline $50-59$ & 175 & 24.8 & 13.1 & $8.9-19.0$ & \\
\hline Race/Color ${ }^{\mathrm{a}}$ & & & & & 0.662 \\
\hline White & 156 & 22.9 & 14.1 & $9.4-20.5$ & \\
\hline Brown & 357 & 52.4 & 13.7 & $10.5-17.7$ & \\
\hline Black & 168 & 24.7 & 16.8 & $11.7-23.1$ & \\
\hline Schooling level (complete years of study) & & & & & 0.001 \\
\hline $0-8$ & 256 & 36.3 & 20.3 & $15.8-25.7$ & \\
\hline More than 8 & 450 & 63.7 & 11.1 & $8.5-14.4$ & \\
\hline Marital Status & & & & & 0.011 \\
\hline Married & 353 & 50.0 & 10.2 & $7.4-13.8$ & \\
\hline Single/Dating & 146 & 20.7 & 17.1 & $11.8-24.2$ & \\
\hline Split/Divorced & 20 & 2.8 & 15.0 & $4.8-38.4$ & \\
\hline Consensual Union & 187 & 26.5 & 20.3 & $15.1-26.7$ & \\
\hline Family income thirds (Reais) & & & & & $0.018^{c}$ \\
\hline Up to $1.500,00$ & 227 & 32.1 & 17.6 & $13.2-23.2$ & \\
\hline $1.501,00$ to $2.924,00$ & 222 & 31.4 & 16.2 & $11.9-21.7$ & \\
\hline Above $2.924,00$ & 257 & 36.4 & 10.1 & $7.0-14.5$ & \\
\hline \multicolumn{6}{|c|}{ Behavior } \\
\hline Ingests alcoholic drinks (currently) & & & & & 0.414 \\
\hline No & 464 & 65.7 & 14.1 & $10.8-18.2$ & \\
\hline Yes & 242 & 34.3 & 16.5 & $12.3-21.8$ & \\
\hline Smokes (currently) & & & & & 0.027 \\
\hline No & 507 & 71.8 & 12.4 & $9.8-15.6$ & \\
\hline Yes & 83 & 11.8 & 22.9 & $15.0-33.2$ & \\
\hline Former smoker & 116 & 16.4 & 17.2 & $11.4-25.3$ & \\
\hline Drug use history & & & & & 0.032 \\
\hline No & 642 & 90.9 & 13.6 & $11.1-16.4$ & \\
\hline Yes & 64 & 9.1 & 23.4 & $14.6-35.4$ & \\
\hline \multicolumn{6}{|c|}{ Obstetric and gynecologic } \\
\hline Menarche age (years) & & & & & 0.352 \\
\hline Until 14 & 577 & 81.7 & 13.9 & $11.3-16.9$ & \\
\hline Older than 14 & 129 & 18.3 & 17.0 & $11.5-24.6$ & \\
\hline Using contraceptive methods ${ }^{b}$ & & & & & 0.346 \\
\hline No & 98 & 21.8 & 18.4 & $11.5-27.4$ & \\
\hline Yeas & 352 & 78.2 & 14.5 & $11.1-18.6$ & \\
\hline Number of pregnancies & & & & & $0.002^{c}$ \\
\hline None & 54 & 7.7 & 7.4 & $2.8-18.3$ & \\
\hline $1-2$ & 310 & 43.9 & 11.0 & $7.9-15.0$ & \\
\hline 3 or more & 342 & 48.4 & 18.7 & $14.9-23.2$ & \\
\hline Sexual debut age (years) & & & & & $0.000^{c}$ \\
\hline Younger than 15 & 70 & 9.9 & 30.0 & $20.4-41.8$ & \\
\hline $15-18$ & 381 & 54.0 & 14.4 & $11.2-18.3$ & \\
\hline 19 or older & 255 & 36.1 & 10.2 & $7.0-14.6$ & \\
\hline Number of sexual partners in the last year & & & & & 0.001 \\
\hline 1 & 639 & 90.5 & 13.0 & $10.6-15.8$ & \\
\hline 2 or more & 67 & 9.5 & 28.4 & $18.8-40.3$ & \\
\hline
\end{tabular}


Higher predominance of overdue tests was observed among the women who suffered any type of IPV, when compared to the ones who did not report this experience (Table 2).

Women who were victims of IPV in the last 12 months, regardless the type of violence inflicted, had higher prevalence of not performing the Pap test in the last three years in relation to the ones who did not suffer aggressions in the gross analysis (Table 3).

In the adjusted analysis for sociodemographic, schooling levels, marital status, and family income variables, being exposed to psychological violence did not remain associated to not performing the test $(\mathrm{p}=0.097)$. This result was confirmed by the model 2 , which included behavior, obstetric and gynecological variables as possible confounding factors for this association ( $\mathrm{p}=0.214)$ (Table 3$)$.

Regarding the implications of sexual and physical violence in cervical cancer screening, after the adjustment by model 1 (age, schooling levels, marital status, and income), a decrease in the gross average was observed, suggesting a positive confusion of these variables. In the final adjustment, a reduction in the effect measure was also observed, indicating a distortion of this association by the obstetric and gynecological variables. However, even after the control of all possible confounding factors, the association remained significant

Table 2. Prevalence of not performing the cytopathologic test in the last three years according to the type of violence suffered in the last 12 months. Vitória, state Espírito Santo, March to September 2014. $(\mathrm{n}=706)$

\begin{tabular}{lcccc}
\hline IPV in the last $\mathbf{1 2}$ months & $\mathbf{n}$ & $\%$ & $\mathbf{9 5} \mathbf{0} \mathbf{C l}$ & $\mathbf{p}$ \\
\hline Psychological violence & & & & \\
$\quad$ No & 525 & 12.8 & $10.2-15.9$ & 0.030 \\
$\quad$ Yes & 181 & 19.3 & $14.2-25.8$ & \\
Sexual violence & & & & \\
$\quad$ No & 661 & 13.5 & $11.1-16.3$ & 0.004 \\
$\quad$ Yes & 45 & 28.9 & $17.5-43.8$ & \\
Physical violence & & & & \\
$\quad$ No & 643 & 12.9 & $10.5-15.7$ & 0.000 \\
$\quad$ Yes & 63 & 30.2 & $20.1-42.6$ & \\
General violence & & & & \\
$\quad$ No & 508 & 12.2 & $9.6-15.4$ & 0.007 \\
$\quad$ Yes & 198 & 20.2 & $15.2-26.4$ & \\
\hline
\end{tabular}

IPV: Intimate partner violence.

Table 3. Crude and adjusted analysis of the effects of intimate partner violence in the last 12 months, and not performing the cytopathologic test in the last three years. Vitória, state Espírito Santo, March to September 2014. ( $\mathrm{n}=706)$

\begin{tabular}{|c|c|c|c|c|c|c|c|c|c|c|}
\hline $\begin{array}{l}\text { Violence in the } \\
\text { last } 12 \text { months }\end{array}$ & $\mathbf{n}$ & Crude PR & $95 \% \mathrm{Cl}$ & p & Adjusted PR 1 & $95 \% \mathrm{Cl}$ & p & Adjusted PR 2 & $95 \% \mathrm{Cl}$ & p \\
\hline \multicolumn{11}{|l|}{ Psychological } \\
\hline No & 525 & 1.0 & & 0.029 & 1.0 & & 0.097 & 1.0 & & 0.214 \\
\hline Yes & 181 & 1.52 & $1.05-2.20$ & & $1.36^{\mathrm{a}}$ & $0.95-1.97$ & & $1.25^{\mathrm{b}}$ & $0.88-1.79$ & \\
\hline \multicolumn{11}{|l|}{ Sexual } \\
\hline No & 661 & 1.0 & & 0.003 & 1.0 & & 0.015 & 1.0 & & 0.046 \\
\hline Yes & 45 & 2.15 & $1.30-3.53$ & & $1.82^{\mathrm{a}}$ & $1.12-2.95$ & & $1.64^{\mathrm{c}}$ & $1.03-2.62$ & \\
\hline \multicolumn{11}{|l|}{ Physical } \\
\hline No & 643 & 1.0 & & 0.000 & 1.0 & & 0.001 & 1.0 & & 0.002 \\
\hline Yes & 63 & 2.34 & $1.53-3.58$ & & $2.10^{\mathrm{a}}$ & $1.38-3.21$ & & $1.94^{\mathrm{b}}$ & $1.28-2.93$ & \\
\hline \multicolumn{11}{|l|}{ General } \\
\hline No & 508 & 1.0 & & 0.006 & 1.0 & & 0.034 & 1.0 & & 0.078 \\
\hline Yes & 198 & 1.66 & $1.15-2.38$ & & $1.48^{\mathrm{a}}$ & $1.03-2.12$ & & $1.37^{\mathrm{b}}$ & $0.97-1.94$ & \\
\hline
\end{tabular}

a Schooling level, marital status, and income.

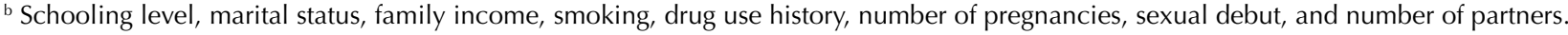

c Schooling level, marital status, number of pregnancies, sexual debut, and number of partners. 
( $\mathrm{p}<0.05$ ), that is, women exposed to sexual and physical violence by their intimate partner had, respectively, $64 \%$ and $94 \%$ higher prevalence of not performing the Pap test in the last three years than the non-victim ones (Table 3 ).

\section{DISCUSSION}

14.5\% users of health services in Vitória, state Espírito Santo, who were from 30 to 59 years old, have not undergone the cervical cancer preventive test in the last three years. This result resembles the finding of the Pesquisa de Vigilância de Fatores de Risco e Proteção para Doenças Crônicas por Inquérito Telefônico (VIGITEL - Vigilance Research of Risk Factors and Chronical Disease Protection via Telephone Inquiry). According to the study, in 2015, about $87 \%$ of women in Vitória performed the cytopathologic test in the last three years, that is, $13 \%$ did not undergo the test ${ }^{16}$. Such finding points out that the health services in the municipality have been reaching the goal stablished by the Programa Nacional do Prevenção do Câncer de Colo do Utero (National Program for Cervical Cancer Prevention), which proposes a cytopathologic test coverage of $80 \%$ to $85 \%$ of the female population, having a test for each three years ${ }^{5}$.

Despite the results suggesting that a significant percentage of women undergoes the Pap test according to the interval recommended by the Brazilian Ministry of Health, certain groups perform it less. This indicates the influence of some factors in the cervical cancer prevention actions.

The prevalence of not performing the Pap test in the last three years was associated to the woman's conjugal situation. Single women presented higher prevalence of overdue tests in a research performed in Florianópolis, state Santa Catarina ${ }^{7}$. In our study, the higher percentage of not performing the test happened for women living with a partner, but unmarried, that is, who are in a consensual union. This result can be related to aspects as this women's submission to their partners ${ }^{17}$, and also to the idea that a stable union stablishes an obstacle to the multiplicity of partners and, consequently, provides the woman with a certain degree of immunity to Sexually Transmitted Infections (STI), which is not true ${ }^{18}$.

Likewise this research, a study performed in Feira de Santana, state Bahia, has showed that women with lower schooling levels and more children have had higher prevalence of not performing the Pap test $^{19}$.It was also observed a higher overdue test rates for women who has their first sexual relation before 15 years-old and more than two sexual partners in the year previous to the interview. This result is particularly concerning, given that the multiplicity of partners is connected to a higher risk for HPV infection, a necessary condition for developing cervical cancer ${ }^{20}$.

This is the first Brazilian epidemiologic study with users of the primary care that assesses the association between IPV and not performing the Pap test. The results are concerning and show that women who suffered IPV are more prone to having overdue Pap tests. Even after the control for possible confounding factors, it was verified, among sexual violence victims, a $64.0 \%$ prevalence of not undergoing the test in the last three years, while for the ones that suffered physical violence, the prevalence of overdue cytopathologic tests is almost twice as bigger $(\mathrm{p}<0.05)$. Despite the non-association to psychological violence, $25 \%$ of victims of this kind of abuse have overdue cervical cancer prevention tests $(p=0.214)$.

It is important to interpret the presented estimates with caution, since this study's data concern women who use primary care in a single Brazilian municipality, not representing the female population as a whole. Therefore, generalizing the results must be carried out cautiously. However, this must be considered, specially when analyzing the prevalence of outcomes and exposition, given that it is not necessary to perform a population-based study to investigate associations. Still, the possibility of a recall bias must be considered, since women tend to underestimate the time gone since they last performed the Pap test. However, self-reporting is widely used in national ${ }^{7,19}$ and international ${ }^{10,21,24}$ research, which were used for comparing and discussing the results in this study. 
Studies on the association between violence against women and cervical neoplasia screening in Brazil were not found. Internationally, few are the published studies and those present methodological differences, which can justify the discrepancies between estimations and presented associations. A population-based American study with women aging from 18 to 45 years-old has shown that IPV was not related to performing the Pap test $(\mathrm{p}=0.623)^{22}$. A research with 101 women diagnosed with breast, cervical, endometrial, or ovarian cancer has also showed no differences in cervical cancer screening for victimized and non-victimized women $(\mathrm{p}=0.062)^{23}$. Likewise, a population-based study with Australian women did not find any significant association between violence against women and cervical cancer screening $(\mathrm{OR}=1.18 \text {; 95\%CI } 0.99-1.40)^{24}$. The associations were close to the significance threshold in the last two studies.

In opposition, other studies have stablished a relation between being victimized and performing the test. Women who experienced physical or sexual violence, done by an intimate partner, had two times more chances of having performed the Pap test ( $\mathrm{OR}=2.05$; $95 \%$ CI $1.26-3.31)^{10}$ when compared to non-victims. Similarly, another research has showed that the chances of performing the Pap test were higher for women who suffered physical intimate partner violence $(\mathrm{OR}=2.39 ; 95 \% \mathrm{CI} 1.01-5.70)^{25}$.

Despite de methodology differences, specially regarding the measurement of violence, which is considered a complex event, the results in this study converge with the evidence reported by some authors ${ }^{9,21}$. Women users in the health service, aging from 40 to 74 years-old, who were victim of emotional abuse, when compared to the victims of physical or sexual abuse, had $87 \%$ less chances of having their Pap tests up-to-date $(\mathrm{OR}=0.13 \text {; 95\% CI } 0.02-0.86)^{21}$. Women who were sexually abused before 18 years-old were also less prone to perform cervical cancer screening ( $35 \%$ versus $51 \% ; \mathrm{n}=694 ; \mathrm{p}=0.009)^{9}$.

Although women exposed to violence access health services more frequently due to the physical and mental demands ${ }^{26}$, such access usually does not implies receiving the recommended preventive services ${ }^{22}$. Experiencing violence, specially sexual violence, may restrict the woman's search for gynecologic appointments, due to shame of fear of retaliation by the partner, or even to the threat of unveiling the suffered violence. The gynecologic exam for victims, specially if performed coldly and carelessly, without explaining the procedure and its meaning, can become a moment of reliving the painful experience of the violence episode. Thus, instead of being a place of sheltering women, the gynecologic appointment can potentialize the feeling of fear and rejection towards the test ${ }^{4}$.

Besides the risk of physical injury and mental health damage ${ }^{12,13}$, the IPV, specially the sexual violence, makes women experience situations of frequently forced and unprotected sexual relations ${ }^{27}$. This makes the victim more prone to Sexually Transmitted Infections (STI) ${ }^{28}$, as the HPV, which is associated to a higher risk of cervical neoplasia ${ }^{29}$.

Still, the complex interaction among women under violence situation and the use of preventive services may depend on the type and severity of the experienced violence. All forms of violence have consequences that surpass the physical health sphere, also affecting the victims' mental health. Such fact incapacitates selfcare and the care for others, possibly causing a diminished search for preventive health care ${ }^{4}$.

This study's hypothesis was confirmed, since there was an association between not performing the cytopathologic test in the last three years and the experience of IPV. Therefore, given this context, and considering the impact of violence on the victimized woman's health, health services have an important role on the promotion of preventive screening actions for cases of violence against women, as well as on offering preventive services. Professionals should gather efforts in order to reach these women and promote the opportunity for cervical cancer screening and for a comprehensive care, besides developing in these users the attitude of looking for health prevention and promotion services. 


\section{REFERENCES}

1. World Health Organization, International Agency for Research on Cancer. GLOBOCAN 2012: estimated cancer incidence, mortality and prevalence worldwide in 2012. Lyon (FR): IARC; 2012 [cited 2018 Feb 19]. Available from: http://globocan.iarc.fr/Default.aspx

2. Instituto Nacional de Câncer José Alencar Gomes da Silva, Coordenação Geral de Prevenção e Vigilância. Estimativas 2016: incidência de câncer no Brasil. Rio de Janeiro: INCA; 2015 [cited 2018 Feb 19]. Available from: http://www.inca.gov.br/bvscontrolecancer/publicacoes/ edicao/Estimativa_2016.pdf

3. Zardo GP, Farah FP, Mendes FG, Franco CAGS, Molina GVM, Melo GN, et al. Vacina como agente de imunização contra o HPV. Cienc Saude Coletiva. 2014;19(9):3799-808. https://doi.org/10.1590/1413-81232014199.01532013

4. Pinho AA, França-Júnior I. Prevenção do câncer de colo do útero: um modelo teórico para analisar o acesso e a utilização do teste de Papanicolaou. Rev Bras Saude Mater Infant. 2003;3(1):95-112. https://doi.org/10.1590/S1519-38292003000100012

5. Instituto Nacional de Câncer José Alencar Gomes da Silva, Coordenação de Prevenção e Vigilância, Divisão de Detecção Precoce e Apoio à Organização de Rede. Diretrizes brasileiras para o rastreamento do câncer de colo do útero. 2.ed.rev.ampl. atual. Rio de Janeiro: INCA; 2016 [cited 2018 Feb 19]. Available from: http://www1.inca.gov.br/inca/Arquivos/Diretrizes_ para_o_Rastreamento_do_cancer_do_colo_do_utero_2016_corrigido.pdf

6. Borges MFSO, Dotto LMG, Koifman RJ, Cunha MA, Muniz PT. Prevalência do exame preventivo de câncer do colo do útero em Rio Branco, Acre, Brasil, e fatores associados à não-realização do exame. Cad Saude Publica. 2012;28(6):1156-66. https://doi.org/10.1590/S0102-311X2012000600014

7. Gasperin SI, Boing AF, Kupek E. Cobertura e fatores associados à realização do exame de detecção do câncer de colo de útero em área urbana no Sul do Brasil: estudo de base populacional. Cad Saude Publica. 2011;27(7):1312-22. https://doi.org/10.1590/S0102-311X2011000700007

8. Ferreira MLSM. Motivos que influenciam a não-realização do exame de papanicolaou segundo a percepção de mulheres. EsC Anna Nery. 2009;13(2):378-84. https://doi.org/10.1590/S1414-81452009000200020

9. Farley M, Golding JM, Minkoff JR. Is a history of trauma associated with a reduced likelihood of cervical cancer screening? J Fam Pract. 2002;51(10):827-31.

10. Brown MJ, Weitzen S, Lapane KL. Association between intimate partner violence and preventive screening among women. J Womens Health. 2013;22(11):947-52. https://doi.org/10.1089/jwh.2012.4222

11. World Health Organization. Global and regional estimates of violence against women: prevalence and health effects of intimate partner violence and non-partner sexual violence. Geneva: WHO; 2013 [cited 2018 Feb 19]. Available from: http://apps.who.int/iris/ bitstream/10665/85239/1/9789241564625_eng.pdf

12. Kernic MA, Wolf ME, Holt VL. Rates and relative risk of hospital admission among women in violent intimate partner relationships. Am J Public Health. 2000;90(9):1416-20. https://doi.org/10.2105/AJPH.90.9.1416

13. Coker AL, Smith PH, Bethea L, King MR, McKeown RE. Physical health consequences of physical and psychological intimate partner violence. Arch Fam Med. 2000;9(5):451-7. https://doi.org/10.1001/archfami.9.5.451

14. Mascarello KC, Silva NF, Piske MT, Viana KCG, Zandonade E, Amorim MHC. Perfil sociodemográfico e clínico de mulheres com câncer do colo do útero associado ao estadiamento inicial. Rev Bras Cancerol. 2012 [cited 2018 Feb 19];58(3):417-26. Available from: http://www.inca.gov.br/rbc/n_58/v03/pdf/11_artigo_perfil_sociodemografico_clinico_mulheres_ cancer_colo_utero_associado_estadiamento_inicial.pdf

15. Schraiber LB, Latorre MRDO, França Jr I, Segri NJ, D'Oliveira AFPL. Validity of the WHO VAW study instrument for estimating gender-based violence against women. Rev Saude Publica. 2010;44(4):658-66. https://doi.org/10.1590/S0034-89102010000400009

16. Ministério da Saúde (BR), Secretaria de Vigilância em Saúde, Departamento de Vigilância de Doenças e Agravos Não Transmissíveis e Promoção da Saúde. Vigitel Brasil 2015: vigilância de fatores de risco e proteção para doenças crônicas por inquérito telefônico: estimativas sobre frequência e distribuição sociodemográfica de fatores de risco e proteção para doenças crônicas nas capitais dos 26 estados brasileiros e no Distrito Federal em 2015. Brasília (DF); 2016 [cited 2018 Feb 19]. Available from: http://bvsms.saude.gov.br/bvs/publicacoes/vigitel_brasil_2015.pdf 
17. Gamarra CJ, Paz EPA, Griep RH. Knowledge, attitudes and practice related to Papanicolaou smear test among Argentina's women. Rev Saude Publica. 2005;39(2):270-6. https://doi.org/10.1590/S0034-89102005000200019

18. Guedes TG, Pordeus AMJ, Diógenes MAR. Análise epidemiológica do câncer de colo de útero em serviço de atendimento terciário no Ceará - Brasil. Rev Bras Promoç Saude. 2005 [cited 2018 Feb 19];18(4):205-10. Available from: http://periodicos.unifor.br/RBPS/article/ view/945/2112

19. Andrade MS, Almeida MMG, Araújo TM, Santos KOB. Fatores associados a não adesão ao Papanicolau entre mulheres atendidas pela Estratégia Saúde da Família em Feira de Santana, Bahia, 2010. Epidemiol Serv Saude. 2014;23(1):111-20. https://doi.org/10.5123/S1679-49742014000100011

20. Rama CH, Roteli-Martins CM, Derchain SFM, Longatto-Filho A, Gontijo RC, Sarian LOZ, et al. Prevalência do HPV em mulheres rastreadas para o câncer cervical. Rev Saude Publica. 2008;42(1):123-30. https://doi.org/10.1590/S0034-89102008000100016

21. Gandhi S, Rovi S, Vega M, Johnson MS, Ferrante J, Chen PH. Intimate partner violence and cancer screening among urban minority women. J Am Board Fam Med. 2010;23(3):343-53. https://doi.org/10.3122/jabfm.2010.03.090124

22. McCall-Hosenfeld JS, Chuang CH, Weisman CS. Prospective association of intimate partner violence with receipt of clinical preventive services in women of reproductive age. Womens Health Issues. 2013;23(2):e109-16. https://doi.org/10.1016/j.whi.2012.12.006

23. Modesitt SC, Gambrell AC, Cottrill HM, Hays LR, Walker R, Shelton BJ, et al. Adverse impact of a history of violence for women with breast, cervical, endometrial or overian cancer. Obstet Gynecol. 2006;107(6):1330-36. https://doi.org/10.1097/01.AOG.0000217694.18062.91

24. Loxton D, Powers J, Schofield M, Hussain R, Hosking S. Inadequate cervical cancer screening among mid aged Australian women who have experienced partner violence. Prev Med. 2009;48(2):184-8. https://doi.org/10.1016/j.ypmed.2008.10.019

25. Lemon SC, Verhoek-Oftedahl W, Donnelly EF. Preventive healthcare use, smoking, and alcohol use among Rhode Island women experiencing intimate partner violence. I Womens Health Gend Based Med. 2002;11(6):555-62. https://doi.org/10.1089/152460902760277912

26. Campbell JC. Health consequences of intimate partner violence. Lancet 2002;359(9314):1331-6. https://doi.org/10.1016/S0140-6736(02)08336-8

27. Raj A, Santana MC, La Marche A, Amaro H, Cranston K, Silverman JG. Perpetration of intimate partner violence associated with sexual risk behaviors among young adult men. Am J Public Health. 2006;96(10):1873-8. https://doi.org/10.2105/AJPH. 2005.081554

28. Raj A, Reed E, Welles SL, Santana MC, Silverman JG. Intimate partner violence perpetration, risky sexual behavior, and STI/HIV diagnosis among heterosexual African American men. Am J Mens Health. 2008;2(3):291-5. https://doi.org/10.1177/1557988308320269

29. Pinto AP, Tulio S, Cruz OR. Co-fatores do HPV na oncogênese cervical. Rev Assoc Med Bras. 2002;48(1):73-8. https://doi.orgt/10.1590/S0104-42302002000100036

Funding: Fundação de Amparo à Pesquisa e Inovação do Espírito Santo (FAPES - Espírito Santo Research and Innovation Support Foundation - Process 60530812/12).

Authors' Contribution: Study design and planning: FMCL, DPG, MHCA. Data gathering, analysis and interpretation: FMCL. Manuscript writing: FMCL. Critical review of the manuscript: DPG, MHCA.

Conflict of Interest: The authors declare no conflict of interest. 